The Head-Hunters of Western Amazonas:

the Life and Culture of the Jibaro Indians of Eastern Ecuador and Peru. By Prof. Rafael Karsten. (Societas Scientiarum Fennica: Commentationes Humanarum Litterarum, 7, 1.) Pp. xvi $+598+34$ plates. (Helsingfors: Societas Scientiarum Fennica, 1935.) n.p.

To the outside world, the Jibaros, the "HeadHunters of the Western Amazonas", are best known as the source of the shrunken human heads, which are to be found in most ethnological collections. To the anthropologist, they are the most important members of a race, or group of Indians comprising a large number of tribes, inhabiting eastern Ecuador and Peru, who exemplify the forest culture of South America.

Dr. Karsten has spent an extended period of observation among the Jibaro on two occasions-in 1916-18 and 1928-29. Some results of his first visit were published by the Smithsonian Institution of Washington, D.C., in a memoir which dealt with the technique followed in the preparation of the shrunken heads and the cultural setting of the custom, which plays such an important part in war and religious belief among the members of the tribe. This account, the first, and indeed the only, authoritative report on the practice, is incorporated in the present volume with additions from subsequent observation. This, however, though perhaps the most important, and certainly the most spectacular, result of Dr. Karsten's investigations, is far from exhausting their interest. His fully detailed account of Jibaro culture and economy, and more especially of their feasts and dances, is of no little importance as a contribution to the study of the indigenous peoples of South America.

Dr. Karsten's investigations also covered the Canelos Indians, a group of mixed origin, now some two thousand in number, Christian in name, though preserving many of their pagan customs and beliefs. The Jibaro, on the other hand, though in contact with Europeans from the early days of the Spanish invasion, have sturdily resisted change in culture and language. The effect of outside influence, however, is now growing rapidly, a fact which gives this book an added value.

\section{Mathematics of Modern Engineering}

By Robert E. Doherty and Prof. Ernest G. Keller. Vol. 1. Pp. xxi+314. (New York: John Wiley and Sons, Inc.; London : Chapman and Hall, Ltd., 1936.) 17s. 6d. net.

The manifold problems of modern engineering are making great demands upon the applications of mathematies, and, as a consequence, many textbooks dealing with the mathematical principles underlying such problems are making their appearance. The present volume-one of a series written in the interest of the advanced course in engineering of the General Electric Company-belongs to this class, and, as stated in the preface, is the result of "the joint participation of a mathematician who has worked in engineering, and of an engineer who has worked with mathematics". The book is therefore neither a text on mathematics nor on engineering ; it aims rather at bridging the gulf in engineering between physics and mathematics.

The four chapters consist mainly of the mathematical formulation and solution of modern technical problems. After a short but thoroughly sound introductory chapter, the basic principles of mathematics, essential to the higher problems of engineering, are dealt with. Chapter ii is therefore concerned with differential equations, including graphical and numerical methods of solution; determinants, Fourier series, transcendental equations and dimensional analysis. Then follows a chapter on vector analysis, with special reference to the problems of mathematical physics, and finally, Heaviside's operational calculus is very ably dealt with in Chapter iv. The text is clearly printed and well illustrated, whilst problems and exercises are provided for the student.

Mention should also be made of the very interesting "Foreword for Instructors" which appears at the beginning. This reviews the increasing use which is being made of the applications of mathematics to practical problems, thus clothing the spectre of pure abstraction in a really useful garment.

\section{Electricity}

By Prof. W. L. Bragg. Pp. xi $+286+34$ plates. (London : G. Bell and Sons, Ltd., 1936.) 8s. 6d. net.

Prof. W. L. Bragg's course of six lectures "adapted to a juvenile auditory" delivered at the Royal Institution at Christmas 1934 forms the basis of this book. The first three chapters deal with the behaviour of electric charges, electrical currents and magnets, and with such fundamental apparatus as cells, motors and dynamos. The other chapters deal with power stations and the transmission of electrical current, telegraphs, telephones and wireless. The demonstrations which are a feature of these lectures are, in the book, replaced by many excellent illustrations. Although the language used is simple and the style most pleasing, technical terms are freely used. Prof. Bragg holds the view that as in many cases no equivalent word can be found, it is simpler to explain each technical term as it arises and then to use it freely. There is no mathematics in the book. Units in which electrical quantities are measured are made more realistic by quoting figures from familiar examples.

It is a little regrettable that in such an authoritative account some of the careless abbreviations of units used by radio engineers should have been allowed to creep in, here and there. For example, on p. 261 a frequency of 1,000 kilocycles is mentioned and on p. 266 the statement "The frequency is about thirty million" is made. We are certain Prof. Bragg does not allow his students to talk of a "velocity of a hundred" or even of "a velocity of $100 \mathrm{ft}$. ."

The book can be confidently recommended to those who desire a reliable account of electricity. Teachers and lecturers will also find it a valuable source of ideas for demonstrations and illustrations of obscure points. 
Landolt-Börnstein Physikalisch-chemische Tabellen Fünfte, umgearbeitete und vermehrte Auflage. Herausgegeben von Prof. Dr. W. A. Roth und Prof. Dr. K. Scheel. Ergänzungsband 3, Teil 1. Pp. viii + 734. 108 gold marks. Teil 2. Pp. viii +735-1814. 162 gold marks. (Berlin : Julius Springer, 1935.)

THE third supplement of the familiar "LandoltBörnstein-Roth" tables is divided into three parts since a very large amount of new matter has to be dealt with. The two volumes under review are Parts I and II; Part III, dealing with electrical, magnetic and thermal properties, is to appear during this year.

A glance at the contents reveals some of the directions in which active research has been prosecuted during the last few years. Part 1 contains large additions to the tables of dipole moments, and records a considerable amount of new work on the com. pressibilities of liquids and gases. A new table of the occurrence and relative abundance of isotopes is appropriately introduced, since nearly all the elements have now been analysed. Another new table which indicates the trend of modern work records the nuclear distances and vibration frequencies of simple molecules deduced from infra-red and Raman spectra.

Part 2 contains a large amount of new spectroscopic data, including a useful table of series and terms in line spectra. The Raman effect, which was first tabulated in the second supplement of these tables, occupies 280 pages in the third supplement. New tables in Part 2 include those dealing with hyperfine structure of spectral lines, with band spectra, and with the absorption of light in the infra-red.

There is no need to stress the immense value of the Landolt-Börnstein-Roth tables and their supplements. Physicists and physical chemists owe a debt of gratitude to the present editors, Profs. Roth and Scheel, which is increased by each new volume that is published.

S. S.

\section{L'Ethnie française}

Par Prof. Dr. George Montandon. (Bibliothèque scientifique.) Pp. $240+48$ plates. (Paris : Payot et Cie., 1935.) 30 francs.

Prof. Montandon opens his study of the racial characters of the population of France dramatically with the statement that there is no French race-a statement presumably pour épater le bourgeois, as it is one with which the vast majority of his colleagues in anthropology would have no quarrel, and, indeed, would scarcely regard as novel.

After an exposition of the hologenetic point of view in the origin and distribution of races on the lines of his previous works, of which an excellent summary appears in Scientia for September, 1935, Prof. Montandon describes the distribution of racial characters in the French population so far as it has now been observed, and bases thereon a classification of racial types. His classification, as he points out, differs in certain essentials from that of Deniker, which distinguishes six racial types, three of them belonging or closely related to the Alpine group, and three to the Mediterranean. Prof. Montandon distinguishes four main types with sub-types, and three more or less localised groups, the most important innovation on Deniker's classification being the recognition of a Nordic element with its sub-types. The author maintains that it is possible also to distinguish a Basque type, this differentiation being based mainly on the form of the nose. This type was overlooked by Deniker through his reliance on a too limited number of characters as his basis of classification.

Dr. Montandon's study is a welcome reopening of a question which requires reconsideration in the light of modern methods of inquiry and recent theory.

\section{An Introduction to Astronomy}

By Prof. Robert H. Baker. Pp. vi+312. (London : Macmillan and Co., Ltd., 1935.) 12s. 6d. net.

THE author of this book is professor of astronomy in the University of Illinois. In 1930 he wrote "Astronomy", containing five hundred pages and published by the Van Nostrand Company, New York. The new "Introduction to Astronomy" is a shorter, simpler, but more attractive book, which presents the more essential elements of astronomy in a clear way by means of careful writing, skilful diagrams and good photographs. The charm of the book is somewhat disturbed by examination or revision questions at the end of each chapter. For example, on page 282 is a section headed "Interstellar space is not empty"; and seven pages later comes the question "What are the reasons for believing that interstellar space is not empty ?" There are, however, questions requiring some imagination, such as (p. 305) - "Describe the appearance of the heavens as viewed from somewhere in the arms of Andromeda Nebula". The request to "show that Kepler's laws completely disproved the Ptolemaic system" (p. 160) raises some interesting philosophical questions which recall Poincaré.

This book is entirely devoid of any mathematical formulæ or calculations. The publishers are, however, justified in recommending students to "retain it for your reference library. You will use it many times in the future". Students should not burn their books behind them. No doubt as the evil visage of examinations recedes into the background, there will be more pleasure in life, in astronomy and in the book under review.

\section{An Introduction to Cultural Anthropology}

By Prof. Robert H. Lowie. Pp. xiii + 365. (London : George G. Harrap and Co., Ltd., n.d.) 10s. 6d. net.

STUDENTs of anthropology will welcome an English edition of Dr. Lowie's valuable review of the field covered by the study of cultural anthropology, which appeared in the United States in 1934. In collecting illustrative material, good use has been made of the results which have accrued from the intensive ethnographical study of the tribes of California, now in progress for some years, but comprehensively not so widely known by British students as it deserves. 